\title{
BURNOUT AMONG PHYSIOTHERAPISTS AND LENGTH OF SERVICE
}

\section{ZBIGNIEW ŚLIWIŃSKI ${ }^{1,2}$, MAŁGORZATA STARCZYŃSKA², IRENEUSZ KOTELA ${ }^{2,3}$, TOMASZ KOWALSKI KAROLINA KRYŚ-NOSZCZYK ${ }^{4}$, DANUTA LIETZ-KIJAK ${ }^{5}$, EDWARD KIJAK ${ }^{6}$, and MARTA MAKARA-STUDZIŃSKA ${ }^{4}$}

${ }^{1}$ Physiotherapy Centre, Zgorzelec, Poland

${ }^{2}$ Jan Kochanowski University, Kielce, Poland

Institute of Physiotherapy

${ }^{3}$ Central Clinical Hospital of Ministry of Internal Affairs, Warszawa, Poland

Department of Orthopedics and Traumatology

${ }^{4}$ Medical University of Lublin, Lublin, Poland

Department of Applied Psychology

${ }^{5}$ Pomeranian Medical University, Szczecin, Poland

Department of Dental Physicodiagnostics and Propedeutics

${ }^{6}$ Pomeranian Medical University, Szczecin, Poland

Department of Prosthodontics

\begin{abstract}
Objectives: The aim of this study was to identify factors that contribute to the development of burnout among physiotherapists with different length of service in physiotherapy. Material and Methods: The following research tools were used to study burnout: the Life Satisfaction Questionnaire (LSQ), based on FLZ (Fragebogen zur Lebenszufriedenheit) by Frahrenberg, Myrtek, Schumacher, and Brähler; the Burnout Scale Inventory (BSI) by Steuden and Okła; and an ad hoc questionnaire to collect socio-demographic data. The survey was anonymous and voluntary and involved a group of 200 active physiotherapists working in Poland. Results: A statistical analysis revealed significant differences in overall life satisfaction between length-of-service groups $(\mathrm{p}=0.03)$. Physiotherapists with more than 15 years of service reported greater satisfaction than those with less than 5 years and between 5 and 15 years of service. The results suggest that burnout in those with 5-15 years of service is higher in physiotherapists working in health care centers and increases with age and greater financial satisfaction, while it decreases with greater satisfaction with friend and family relations and greater satisfaction with one's work and profession. In those with more than 15 years of service, burnout increases in the case of working in a setting other than a health care or educational center and decreases with greater satisfaction with one's work and profession. Conclusions: Job satisfaction and a satisfying family life prevent burnout among physiotherapists with 5-15 years of service in the profession. Financial satisfaction, age and being employed in health care may cause burnout among physiotherapists with 5-15 years of service. Physiotherapists with more than 15 years of service experience more burnout if they work in a setting other than a health care or educational center and less burnout if they are satisfied with their profession.
\end{abstract}

Key words:

Stress, Physiotherapy, Burnout, Length of service, Determinants, Fatigue

Received: September 16, 2013. Accepted: January 21, 2014.

Corresponding author: M. Starczyńska, Jan Kochanowski University, Institute of Physiotherapy, IX Wieków Kielc 19, 25-317 Kielce, Poland (e-mail: starm@ujk.edu.pl). 


\section{INTRODUCTION}

The topic of burnout raises a wide interest as a problem related to stressful and difficult working conditions among those caring for the sick. Burnout was first described in the psychological literature by Freudenberger, an American psychiatrist, in 1974. Freudenberger associated burnout with such behaviors as susceptibility to disease, irritability, chronic fatigue, apathy, headache and a general sense of disengagement [1].

Research among health care workers by Maslach showed that emotions accompanying work with people who suffer may be a source of overwhelming emotional tensions. According to Maslach, burnout is characterized by emotional exhaustion and depersonalization $[1,2]$.

According to Freudenberger and Richelson, "burnout is the high cost of high achievement" [3,4]. Burnout is more often experienced by those working with people who are ill, upset and anxious about their condition and its complications. This group includes medical doctors, nurses, psychologists, social workers and physiotherapists [5-9]. A Portuguese study showed that burnout among family physicians increased with the length of their service in the profession [10]. Studies from Lithuania and Argentina showed that $20 \%$ of doctors practicing for more than 15 years suffered from emotional exhaustion and $26 \%$ demonstrated a high degree of depersonalization [11,12]. A Spanish study identified employees with more than 16 years of service as being particularly prone to burnout compared to those who have been working for less than 4 years [13].

Burnout among physiotherapists was first investigated in Massachusetts in 1993 [14], and then in Japan in 2002 [15] and in Italy in 2006 [16]. Risk factors for burnout include high work-related demands, having little control over the outcomes of work, young age and the female sex [17-20]. Other important causes include lack of autonomy, an excessive load of task and responsibilities, lack of feedback on the roles one fulfils and lack of support and help from others [21]. A common sign of burnout is absence from work [22] due to symptoms of depression $[16,17]$ or cardiovascular disease [23,24].

Litzke and Schuh describe three main causes of burnout: overstrain and constant lack of time, lack of independence and autonomy, and inadequate pay. The criteria for assessing one's work and possible promotion are incomprehensible and incompatible with employees' achievements [25]. Sęk states that individuals with a high degree of self-confidence and convinced that they are in control of their own actions are more susceptible to burnout than those who believe they cannot control their lives [26]. A study of a group of physiotherapists in Toronto showed that job satisfaction in the study group was perceived as the professionalization of the occupation exerting a positive influence on patients and the development of physiotherapy as a science [27]. Earlier studies had pointed to such elements of job satisfaction as working environment, amount of salary and communication within the team [28-31].

\section{AIM OF STUDY}

The aim of the study was to identify factors that influence a job fatigue index, predisposing physiotherapists to the development of a burnout syndrome, in different lengthof-service groups.

\section{MATERIAL AND METHODS}

\section{Participants}

The study was carried out between April 2012 and January 2013. One hundred and twenty physiotherapists received the questionnaires to fulfill, but only 200 correct questionnaires of active physiotherapists employed at health care facilities in Poland could be used for the sample. The response rate was $16.66 \%$. The sample was chosen randomly and incidentally. Physiotherapists professionally active were recruited in health care facilities 
such as hospitals, nursing homes, clinics, offices, spas, and educational institutions.

\section{Procedures}

Each respondent received a demographic data sheet and a set of self-rating questionnaires. Participation was anonymous and voluntary. The study procedure was described in detail to each participant before commencing the study. The demographic data sheet was used to collect information about such variables as gender, age, educational status, length of service, position at work.

\section{Measures}

The following self-report questionnaires were used:

\section{Life Satisfaction Questionnaire (LSQ)}

The Life Satisfaction Questionnaire (Fragebogen zur Lebenszufriedenheit - FLZ) by Frahrenberg et al. was developed in 1998, and translated from German into Polish in 2000 by Januszewski and Zając [32] and adapted by Chodkiewicz. The Polish version has good psychometric properties [32]. Cronbach's $\alpha$ values ranged from 0.80 (self-assessment) to 0.96 (health). Accuracy was assessed by comparing Questionnaire scores and the Life Satisfaction Scale of Diener et al. [33] and the SF-36 [34].

The questionnaire is designed for individual and group investigations of healthy and ill adults. It consists of 70 items in the form of declarative sentences describing various aspects of life that represent potential sources of satisfaction. The Life Satisfaction Questionnaire comprises 10 domain scales with the same number of items (7) in each of them. Responses are assigned between 1 and 7 points, where a score of 1 corresponds to 'very dissatisfied', and a score of 7 means 'very satisfied'. The total score is the sum of scores for individual statements (between 1 and 70 points) and reflects overall satisfaction with life.

The following LSQ domains are distinguished: Health $(\mathrm{H})$; Work and occupation (W\&O); Financial status (FS); Free time (FT); Marriage and partnership (MP); Subject's attitude to their children (SATC); Self-assessment (SA); Sexuality (S); Friends, relatives, acquaintances (FRA); and Housing status (HS).

Respondents evaluate to what degree each statement describes their lives so far and express this degree of agreement with the statement by marking 1 of 7 possible answers.

The internal consistency coefficient (Cronbach's $\alpha$ ) was 0.95 in an analysis of responses of 60 participants for all 70 questions. The power of the test, based on two means for females and males at an alpha of 0.05 , was high, at 1.00 .

The coefficients of reliability of individual domains according to the internal consistency method (Cronbach's $\alpha$ ) were as follows: $\mathrm{H} \alpha=0.92 ; \mathrm{W} \& \mathrm{O} \alpha=0.92 ; \mathrm{FS} \alpha=0.90$; $\mathrm{FT} \alpha=0.87 ; \mathrm{MP} \alpha=0.95 ; \mathrm{SATC} \alpha=0.90 ; \mathrm{SA} \alpha=0.91$; $\mathrm{S} \alpha=0.86 ; \mathrm{FRA} \alpha=0.86$; and $\mathrm{HS} \alpha=0.80$.

\section{Burnout Scale Inventory (BSI)}

Developed in 1998 by Steuden and Okła [35], it comprises 66 items. It was designed to study factors underlying burnout in professionally active individuals and workrelated experiences. Some statements in the questionnaire refer to one's involvement in work and work-related fatigue.

Respondents indicate the level of their agreement with statements by marking 1 of 5 answers: yes, rather yes, I'm not sure, rather not, not. These answers count as scores of 5, 4, 3, 2 and 1 point(s), respectively. The following BSI domains are distinguished: Deterioration in emotional control (DEC, 22 items); Loss of personal involvement (LPI, 15 items); Reduced Personal Efficacy (RPD, 12 items); Narrowing of social contacts (NSC, 10 items); and physical fatigue (PF, 7 items). The overall score is a global index of intensity of job fatigue. There is no question conversion in the BSI. The overall score is a global index of intensity of job fatigue. 
This index is a raw score, while domain means are standardized according to a sten scale. The reliability coefficients for the BSI domains according to the internal consistency method (Cronbach's $\alpha$ ) were as follows: $\mathrm{DEC} \alpha=0.59 ; \mathrm{LPL} \alpha=0.54 ; \mathrm{RPD} \alpha=0.49 ; \mathrm{NSC} \alpha=0.49$; and $\mathrm{PF} \alpha=0.52[35]$.

\section{Statistical design}

The raw data were subjected to a statistical analysis. The values of measurable parameters were summarized as means, medians and standard deviations, and those of non-measurable parameters were described in terms of numbers and percentages. The normality of distributions for measurable data was assessed with the ShapiroWilk W test. The Mann-Whitney U test was used to compare two independent samples, while the Kruskal-Wallis test was used to compare more than two groups. Correlations between variables were assessed with Spearman's correlation analysis (R). Step-wise regression analysis was used to assess the percentage of predicted variance and identify factors accounting for the work fatigue factor (WO), with the exclusion criterion for $\mathrm{F}$ at $\mathrm{p}>0.01$.

The results of regression analysis were presented as values of the adjusted coefficient of determination $\left(\mathrm{R}^{2}\right)$, which corresponds to the percentage of the dependent variable predicted by the independent variables in the model, and the values of coefficients of parameters of the model (Beta). The values and significance levels of t-test statistics (testing the significance of each parameter of the equation) were also given, as were the values and significance levels of the $\mathrm{F}$ test, which tests the values of all parameters collectively. Additionally, the value of the partial correlation coefficient was also given as an index of the contribution of a given independent variable to the variance of the dependent variable. The significance level, indicating statistically significant differences or correlations, was set at $p<0.05$. The data base and statistical analyses were performed with STATISTICA 10.0 (StatSoft, Polska).

\section{RESULTS}

\section{Characteristics of the study group}

The sample comprised a group of 200 physiotherapists aged 20-73 years, out of whom $72 \%(\mathrm{~N}=144)$ were women and $28 \%(\mathrm{~N}=56)$ were men. A small group of men can be an important limitation of this study.

The mean age of the respondents was $36.10 \pm 10.03$ years. Respondents under 30 years of age accounted for $31.5 \%$ $(\mathrm{N}=63)$, with $34 \%(\mathrm{~N}=68)$ of the respondents between 30 and 40 years old, $22 \%(\mathrm{~N}=44)$ between the ages of 41 and 50 years and $12.5 \%(\mathrm{~N}=25) 50$ years old and older (Figure 1). With regard to educational status, $22.5 \%(\mathrm{~N}=45)$ of the respondents held the degree of physiotherapy technician, $21 \%(\mathrm{~N}=42)$ held a BA degree in physiotherapy, $42 \%$ $(\mathrm{N}=84)$ held an MA in physiotherapy, $5 \%(\mathrm{~N}=10)$ had earned a specialization in physiotherapy and $9.5 \%$ $(\mathrm{N}=19$ ) held a PhD degree (Figure 2).

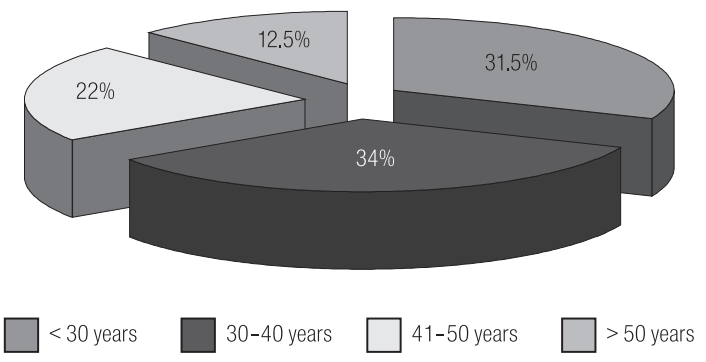

Fig. 1. Respondents with regard to age groups

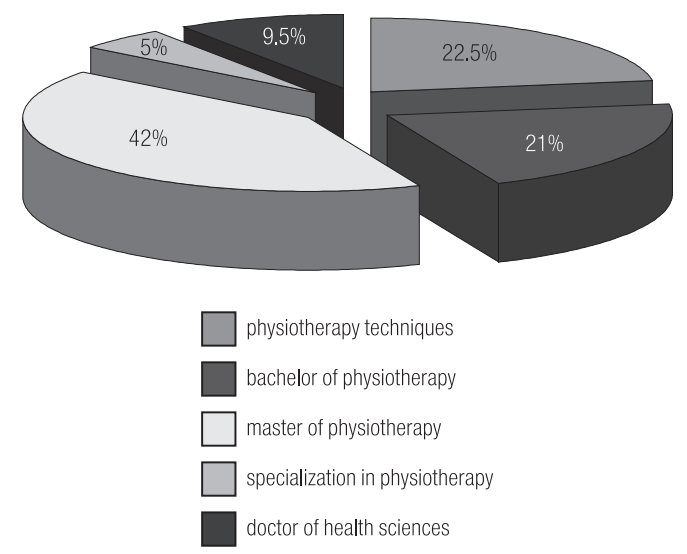

Fig. 2. Respondents with regard to education 
Most respondents had worked as physiotherapists for 15-30 years (35\%), with $11.5 \%$ working for 11-14 years, $7.5 \%$ for $8-10$ years, $19 \%$ for $5-7$ years, $15 \%$ for $3-4$ years, $5.5 \%$ for 2 years and $6.5 \%$ for 1 year.

Seventy-four percent of the respondents worked at health care centers, $4.5 \%$ worked at educational centers, with $12 \%$ combining work in these two settings and $16.5 \%$ working in other settings. Most of the physiotherapists held the position of junior assistant (39.5\%), while $11.5 \%$ worked as assistants, $14.5 \%$ worked as senior assistants, $8.5 \%$ worked as junior technicians, $10 \%$ worked as technicians and $16 \%$ held the position of senior technician.

\section{Levels of burnout among physiotherapists (BSI)}

The analysis showed that the BSI scale had a high reliability, with an internal consistency coefficient (Cronbach's $\alpha$ ) of 0.97 . The mean burnout score was $114.46 \pm 37.85$, $(\mathrm{Me}=108)$, which accounted for $35 \%$ of the theoretical maximum score on this scale (330). Most scores fell within sten 4 or $5(45.5 \%)$, with $27 \%$ of the scores falling into sten 6 or $7,13.5 \%$ falling within stens $8-10$ and $14 \%$ falling within sten 3 (Table 1).
The highest sten scores were obtained for the DEC (deterioration in emotional control) domain, and the lowest for the LPI (loss of personal involvement) domain (Table 2). In assessing the overall level of burnout forces results within $1+3$ sten accounted for $14 \%(\mathrm{~N}=28)$, (low levels of burnout), while $63.5 \%(\mathrm{~N}=127)$ of the results were within 4-6 sten average levels of burnout) and $22.5 \%(\mathrm{~N}=45)$ in the range of 7-10 sten (high levels of burnout) (Figure 3).

\section{Life satisfaction index (LSQ)}

The analysis showed that the LSQ scale had a high reliability, with an internal consistency coefficient (Cronbach's $\alpha$ )

Table 2. Mean sten scores for Burnout Scale Inventory (BSI) domains

\begin{tabular}{lccc}
\hline \multicolumn{1}{c}{ Domain } & Mean & Median & $\begin{array}{c}\text { Standard } \\
\text { deviation }\end{array}$ \\
\hline DEC & 5.56 & 5.00 & 1.86 \\
LPI & 5.44 & 5.00 & 1.93 \\
RPD & 5.46 & 5.00 & 1.90 \\
NSC & 5.53 & 5.00 & 1.76 \\
PF & 5.48 & 5.00 & 2.09 \\
\hline
\end{tabular}

Abbreviations as in Table 1.

Table 1. Assignment of Burnout Scale Inventory (BSI) domain scores to stens

\begin{tabular}{lrrrrrrrrrr}
\hline \multirow{2}{*}{ Sten } & \multicolumn{2}{c}{ DEC } & \multicolumn{2}{c}{ LPI } & \multicolumn{2}{c}{ RPD } & \multicolumn{2}{c}{ NSC } & \multicolumn{3}{c}{ PF } \\
\cline { 2 - 10 }$y$ & $\mathrm{n}$ & \multicolumn{1}{c}{$\%$} & $\mathrm{n}$ & \multicolumn{1}{c}{ \% } & \multicolumn{1}{c}{$\mathrm{n}$} & $\%$ & $\mathrm{n}$ & $\%$ & $\mathrm{n}$ & $\%$ \\
\hline 1 & 0 & 0.00 & 0 & 0.00 & 0 & 0.00 & 0 & 0.00 & 0 & 0.00 \\
2 & 0 & 0.00 & 0 & 0.00 & 0 & 0.00 & 0 & 0.00 & 18 & 9.00 \\
3 & 0 & 0.00 & 27 & 13.50 & 29 & 14.50 & 0 & 0.00 & 19 & 9.50 \\
4 & 80 & 40.00 & 48 & 24.00 & 43 & 21.50 & 67 & 33.50 & 31 & 15.50 \\
5 & 46 & 23.00 & 45 & 22.50 & 40 & 20.00 & 65 & 32.50 & 38 & 19.00 \\
6 & 23 & 11.50 & 34 & 17.00 & 43 & 21.50 & 27 & 13.50 & 29 & 14.50 \\
7 & 22 & 11.00 & 16 & 8.00 & 15 & 7.50 & 12 & 6.00 & 31 & 15.50 \\
8 & 6 & 3.00 & 9 & 4.50 & 13 & 6.50 & 8 & 4.00 & 16 & 8.00 \\
9 & 8 & 4.00 & 9 & 4.50 & 5 & 2.50 & 7 & 3.50 & 11 & 5.50 \\
10 & 15 & 7.50 & 12 & 6.00 & 12 & 6.00 & 14 & 7.00 & 7 & 3.50 \\
\hline
\end{tabular}

DEC - deterioration in emotional control; LPI - loss of personal involvement; RPD - reduced personal efficacy; NSC - narrowing of social contacts; $\mathrm{PF}$ - physical fatigue. 


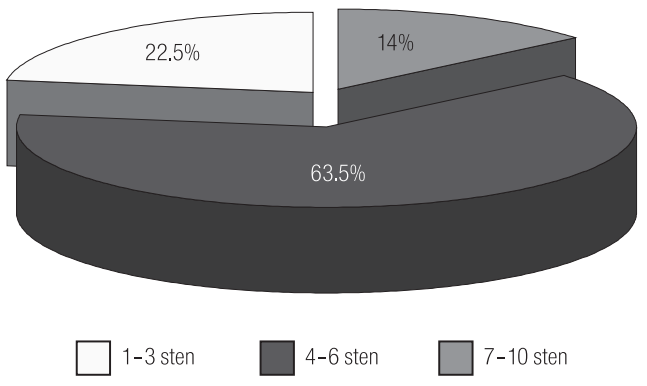

Fig. 3. Sten results to the overall assessment of the Burnout Scale Inventory (BSI)

Table 3. Mean sten scores for Life Satisfaction Questionnaire (LSQ) domains

\begin{tabular}{lccc}
\hline \multicolumn{1}{c}{ Domain } & Mean & Median & $\begin{array}{c}\text { Standard } \\
\text { deviation }\end{array}$ \\
\hline H & 5.50 & 6.00 & 1.91 \\
W\&O & 5.27 & 6.00 & 2.21 \\
FS & 5.25 & 5.00 & 2.18 \\
FT & 5.39 & 6.00 & 2.17 \\
MP & 5.44 & 6.00 & 1.91 \\
SATC & 5.60 & 6.00 & 1.90 \\
SA & 5.42 & 6.00 & 2.01 \\
S & 5.34 & 6.00 & 2.11 \\
FRA & 5.39 & 6.00 & 2.10 \\
HS & 5.35 & 5.00 & 2.10 \\
OLS & 5.49 & 6.00 & 2.03 \\
\hline
\end{tabular}

$\mathrm{H}$ - health; W\&O - work and occupation; FS - financial status; FT - free time; MP - marriage and partnership; SATS - subject's attitude to their children; SA - self-assessment; S - sexuality; FRA - friends, relatives, acquaintances; HS - housing status; OLS - overall life satisfaction.

of 0.97 . The mean burnout score was $321.39 \pm 65.52$ $(\mathrm{Me}=327)$, representing $67 \%$ of the theoretical maximum score on this scale (490). Most individual scores fell within stens $5-7(55 \%)$, with $15 \%$ falling within stens $8-10$, and $30 \%$ within stens $1-4$.

The highest sten scores were obtained for the SATC (subject's attitude towards their children) domain, and the lowest for the FS (financial status) domain (Table 3).

The statistical analysis revealed significant differences in overall life satisfaction scores between length-of-service groups $(\mathrm{p}=0.03)$. Respondents who had been working for 15 years or more reported greater satisfaction than those who had been working for up to 5 years and between 5 and 15 years. There were also significant differences in the Housing Status domain, where those with the longest service as physiotherapists reported greater satisfaction than those with shorter service $(p=0.01)$. There were also near significant differences in the Sexuality domain ( $p=0.06)$, with greater satisfaction declared by those respondents with up to 5 years of service. Analysis of the remaining LSQ domains did not reveal statistically significant differences $(p>0.05)$ (Table 4).

\section{Correlation between satisfaction with life (LSQ) and Burnout Scale Inventory}

The statistical analysis revealed a significant correlation between overall BSI scores and overall and domain LSQ scores, with correlation coefficients between -0.25 and -0.50 . Greater burnout reduced satisfaction with life in each LSQ domain (Table 5).

\section{The impact of selected variables on burnout intensity} among physiotherapists with less than $\mathbf{5}$ years of service The LSQ domains, gender, age, workplace setting and position were analyzed with regard to their impact as variables on the burnout index by regression analysis. No significant statistical model was obtained for the subgroup with less than 5 years of service.

\section{The impact of selected variables on burnout intensity among physiotherapists with 5-15 years of service}

The LSQ domains, gender, age, workplace setting and position were analyzed with regard to their impact as variables on the burnout index by regression analysis. A significant model $(\mathrm{p}<0.00001)$ was obtained for this group. It predicted $68 \%$ of the variance of the SA variable. The model comprised the following variables: FRA, 
Table 4. Life Satisfaction Questionnaire (LSQ) domain scores by length of service

\begin{tabular}{lccccccccccc}
\hline \multirow{2}{*}{ Domain } & \multicolumn{3}{c}{$<5$ years } & \multicolumn{3}{c}{ 5-15 years } & \multicolumn{3}{c}{$>15$ years } & \multicolumn{3}{c}{ Statistical analysis } \\
\cline { 2 - 11 } & $\mathrm{M}$ & $\mathrm{Me}$ & $\mathrm{SD}$ & $\mathrm{M}$ & $\mathrm{Me}$ & $\mathrm{SD}$ & $\mathrm{M}$ & $\mathrm{Me}$ & $\mathrm{SD}$ & $\mathrm{H}$ & $\mathrm{p}$ \\
\hline OLS & 304.57 & 308.00 & 65.16 & 323.09 & 328.00 & 62.70 & 332.68 & 342.00 & 64.15 & 7.13 & $0.03^{*}$ \\
H & 36.57 & 36.00 & 5.31 & 35.29 & 37.00 & 6.41 & 35.79 & 36.00 & 7.47 & 0.86 & 0.65 \\
W\&O & 33.21 & 34.00 & 6.93 & 32.74 & 34.00 & 8.42 & 32.22 & 33.00 & 8.87 & 0.37 & 0.83 \\
FS & 25.18 & 25.00 & 7.98 & 25.82 & 26.00 & 8.89 & 25.53 & 25.50 & 9.13 & 0.06 & 0.97 \\
FT & 30.35 & 32.00 & 8.93 & 28.36 & 28.00 & 8.79 & 27.36 & 28.00 & 8.70 & 4.78 & 0.09 \\
MP & 41.18 & 42.00 & 5.63 & 39.19 & 41.00 & 7.48 & 38.16 & 39.00 & 7.98 & 3.92 & 0.14 \\
SATC & 43.36 & 43.00 & 4.60 & 41.37 & 43.00 & 6.00 & 41.78 & 43.00 & 6.07 & 0.74 & 0.69 \\
SA & 37.69 & 38.00 & 6.28 & 36.32 & 38.00 & 6.72 & 36.21 & 36.00 & 6.21 & 1.38 & 0.50 \\
S & 38.74 & 40.00 & 7.96 & 35.94 & 38.00 & 7.64 & 36.32 & 38.00 & 7.70 & 5.64 & 0.06 \\
FRA & 36.50 & 37.50 & 6.45 & 37.05 & 37.00 & 5.99 & 37.19 & 37.50 & 5.33 & 0.35 & 0.83 \\
HS & 32.67 & 32.00 & 7.26 & 35.78 & 36.00 & 5.06 & 36.15 & 37.00 & 6.58 & 9.21 & $0.01 *$ \\
\hline
\end{tabular}

M - mean; Me - median; SD - standard deviation; $\mathrm{H}$ - Kruskal-Wallis test.

* Statistically significant.

Other abbreviations as in Table 3.

Table 5. Correlation between overall Burnout Scale Inventory (BSI) scores and domain Life Satisfaction Questionnaire (LSQ) scores

\begin{tabular}{lcc}
\hline \multirow{2}{*}{ Domains } & \multicolumn{2}{c}{ Statistical analysis } \\
\cline { 2 - 3 } & $\mathrm{R}$ & $\mathrm{p}$ \\
\hline OLS & -0.47 & $<0.000001^{*}$ \\
$\mathrm{H}$ & -0.49 & $<0.000001^{*}$ \\
W\&O & -0.47 & $<0.000001^{*}$ \\
FS & -0.25 & $0.0006^{*}$ \\
FT & -0.48 & $<0.000001^{*}$ \\
MP & -0.31 & $0.00006^{*}$ \\
SATC & -0.34 & $0.0001^{*}$ \\
SA & -0.50 & $<0.000001^{*}$ \\
S & -0.35 & 0.000001 \\
FRA & -0.41 & $<0.000001^{*}$ \\
HS & -0.21 & $0.004^{*}$ \\
\hline
\end{tabular}

$\mathrm{R}$ - coefficient of determination.

* Statistically significant.

Other abbreviations as in Table 3. workplace setting - health care center, W\&O, FS and age (Table 6).

The estimated linear regression equation was expressed as the following formula:

$$
\begin{gathered}
\mathrm{SA}_{5-15 \text { years of service }}=188.0690-2.8603 \mathrm{FRA}+ \\
+ \text { workplace setting-health care center }+ \\
-1.7581 \mathrm{~W} \& \mathrm{O}+0.111140 \mathrm{FS}+1.4557 \text { Age } \pm 25.867
\end{gathered}
$$

where:

SA - self-assessment,

FRA - friends, relatives, acquaintances,

W\&O - work and occupation,

FS - financial status.

Analysis of variance showed that of the overall sum of squares of the variable SA, 39\% of the variance could not be predicted by regression. The estimation errors and high significance of the parameters confirm a good fit of the model.

These data show that burnout among physiotherapists with between 5 and 15 years of service increased in health 
Table 6. Regression model of the variable SA for physiotherapists with 5-15 years of service

\begin{tabular}{lrrrrrl}
\hline \multicolumn{1}{c}{ Factors } & \multicolumn{1}{c}{$\beta$} & SE of $\beta$ & $\mathrm{b}$ & $\mathrm{SE}$ of $\mathrm{b}$ & $\mathrm{t}$ & $\mathrm{p}$ \\
\hline Friends, relatives, acquaintances & -0.437 & 0.092 & -2.860 & 0.604 & -4.738 & 0.00001 \\
Workplace setting - health care setting & 0.346 & 0.086 & 27.631 & 6.856 & 4.030 & 0.0002 \\
Work and occupation & -0.379 & 0.110 & -1.758 & 0.512 & -3.437 & 0.001 \\
Financial status & 0.247 & 0.111 & 1.098 & 0.495 & 2.220 & 0.03 \\
Age & 0.178 & 0.080 & 1.456 & 0.656 & 2.220 & 0.03 \\
\hline
\end{tabular}

SA - self-assessment; $\beta$ - standardized coefficient; $b$ - regression coefficient; $\mathrm{t}$ - $\mathrm{t}$-test; $\mathrm{SE}$ - standard error.

$\mathrm{R}^{2}$ adjusted $=0.61 ; \mathrm{F}=19.75 ; \mathrm{p}<0.00001$.

Table 7. Regression model of the variable WO for physiotherapists with more than 15 years of service

\begin{tabular}{lcccccc}
\hline \multicolumn{1}{c}{ Factors } & $\beta$ & SE of $\beta$ & $b$ & SE of b & t & p \\
\hline $\begin{array}{l}\text { Workplace setting }- \text { other than health care center } \\
\text { or university }\end{array}$ & 0.446 & 0.096 & 13.799 & 2.969 & 4.647 & 0.00002 \\
Work and occupation & -0.402 & 0.096 & -1.619 & 0.386 & -4.197 & 0.00008 \\
\hline
\end{tabular}

WO - work fatigue factor.

$\mathrm{R}^{2}$ adjusted $=0.42 ; \mathrm{F}=23.22 ; \mathrm{p}<0.00001$.

Other abbreviations as in Table 6 .

care centers with age and greater satisfaction with one's financial status and decreased with higher levels of satisfaction with friends, relatives and acquaintances and greater satisfaction with one's work and occupation.

\section{The impact of selected variables on burnout intensity} among physiotherapists with more than $\mathbf{1 5}$ years of service The LSQ domains, gender, age, workplace setting and position were analyzed with regard to their impact as variables on the burnout index by regression analysis. A significant model $(p<0.00001)$ was obtained for this group. It predicted $42 \%$ of the variance of the variable SA. The model comprised the following variables: workplace setting - another setting and $\mathrm{W} \& \mathrm{O}$ (Table 7).

The estimated linear regression equation was expressed as the following formula:

$$
\begin{gathered}
\mathrm{SA}_{\text {more than 15 years of service }}=157.1219-2+ \\
+ \text { another workplace setting }-1.76189 \mathrm{~W} \& \mathrm{O} \\
\pm 27.660
\end{gathered}
$$

Analysis of variance showed that of the overall sum of squares of the variable SA, $58 \%$ of the variance could not be predicted by regression. The estimation errors and high significance of the parameters confirm a good fit of the model.

These data show that burnout among physiotherapists with more than 15 years of service increased in workplace settings other than health care centers or educational centers and decreased with higher levels of satisfaction with one's work and occupation.

\section{DISCUSSION}

The daily work of a physiotherapist puts considerable strain on the articular, skeletal and muscular systems. Such ailments as joint or back pain, muscle tension and crural varices are associated with excessive exertion that physiotherapists endure in their daily work (kinesiotherapy, helping patients assume a standing position and 
transferring them, massage). A review of the literature indicates that many physiotherapists complain of functional musculoskeletal pain associated with performance of their professional duties [36].

The current progress in medicine and availability of new diagnostic and therapeutic techniques require that physiotherapists continuously improve their skills and qualifications. The high level of professional competence among these medical professionals does not translate into appropriate salary. The lack of a well-defined range of responsibilities contributes to physiotherapists less frequently declaring satisfaction with their work.

The payment system is a problem for medical professionals as systems in operation do not usually reflect the workload. In order to ensure an adequate standard of living, physiotherapists often take on additional jobs, thus allotting limited time to being with their relatives, hobbies and rest. The literature indicates that demographic factors such as educational status or salary level have a 10-15\% effect [37] on one's sense of satisfaction with life and overall life satisfaction [38-40]. Another problem is that health care professionals often feel left on their own with their emotional problems stemming from poor interpersonal communication. It is still regarded as embarrassing to consult a psychologist and it is believed that psychotherapy is generally ineffective. An important concept related to burnout is "distancing of care"; in the health care setting it refers to the combination of compassion with an emotional distance. Those caring for the health of others should avoid forming strong emotional bonds with their patients and should remain objective.

The present results indicate that experienced physiotherapists experience greater satisfaction and less frequently identify with burnout, which is consistent with data from the literature. Health care professionals in Brazil complain of emotional exhaustion even though they have been working for less than 5 years [41].

The results show that with increasing frequency of feelings of anxiety, stress, resentment and helplessness among physiotherapists, their health and mood deteriorate, immunity decreases and overall physical health is impaired. When exposed to stressful factors, individuals who have more frequently experienced positive emotions find it easier to cope with stressful situations and less frequently become depressive [42,43].

A 2010 study in Cyprus showed that nearly half (46\%) of physiotherapists were convinced that their work was stressful. Physiotherapists working in the public health care sector were exposed to particularly high level of stress. Burnout was reported by $21.1 \%$ of the subjects, $21.6 \%$ of those married, $18 \%$ of those living alone and $33.3 \%$ of those who were separated. Emotional exhaustion was most strongly influenced by low pay and stress [44]. The literature on work-related stress places some emphasis on the worker's family situation, including marital status, as a determinant of burnout. Burnout cannot be viewed in isolation from the effect of satisfaction with life [45]. Studies show that divorced persons are a risk group [46,47]. The results of the present study confirm a positive impact of contact of active physiotherapists with friends and family, acquaintances and relatives on the prevention of burnout.

\section{CONCLUSIONS}

1. In the group of physiotherapists with 5-15 years of service, absence of burnout is owed to satisfaction with one's work and occupation and the positive feelings associated with interaction with friends and family.

2. Physiotherapists with 5-15 years of service are prone to experience burnout with age, working at a health care center and increasing satisfaction with their financial status.

3. In the group of physiotherapists with more than 15 years of service, the prevalence of burnout increases among those who work at other settings than a health care or educational center and decreases with increasing satisfaction with one's occupation. 
4. Women who are satisfied with their children, family, health, free time and contacts with friends, relatives and acquaintances are less prone to burnout.

5. Improving staff happiness may contribute to decrease burnout.

\section{REFERENCES}

1. Maslach C. [Burnout: loss of concern for the man]. In: Zimbardo PG, Ruch FL, editors. [Psychology and Life]. Warszawa: Wydawnictwo Naukowe PWN; 1994. Polish.

2. Workshops: assertiveness, coping with stress, preventing burnout. Handouts of the project: Raising the qualifications of instructors, occupational therapy - courses and training]. Ząbki: Stowarzyszenie Rodzin i Przyjaciół Osób z Zaburzeniami Psychicznymi "EMPATIA"; 2010. Polish.

3. Sęk H. [Burnout causes, mechanisms, prevention]. Warszawa: Wydawnictwo Naukowe PWN; 2000. Polish.

4. Sęk H. [Determinants and mechanisms of burnout in the social model of cognitive psychology]. In: Sęk H, editor. [Burnout causes, mechanisms, prevention]. Warszawa: Wydawnictwo Naukowe PWN; 2004. Polish.

5. Sandrin L. [How not to burn out helping others. Ways of overcoming professional burnout syndrome]. Kielce: Wydawnictwo Jedność; 2006. Polish.

6. Karanikola M, Papathanassoglou E, Giannakopoulou M, Koutroubas A. Pilot exploration of the association between self-esteem and professional satisfaction in Hellenic Hospital nurses. J Nurs Manag. 2007;15:78-90, http://dx.doi. org/10.1111/j.1365-2934.2006.00673.x.

7. Jimmieson NL. Employee reactions to behavioral control under conditions of stress: The moderating role of self-efficacy. Work Stress. 2000;14(3):262-80, http://dx.doi.org/10.1080/ 02678370010015343.

8. Soler JK, Yaman H, Esteva M, Dobbs F, Spiridonova-Asenova R, Katic M, et al. Burnout in European family doctors: The EGPRN Study. Fam Pract. 2008;25:245-65, http://dx.doi. org/10.1093/fampra/cmn038.
9. Demir A, Ulosoy M, Ulosoy MF. Investigation of factors influencing burnout levels in professional and private lives of nurses. Int J Nurs Study. 2003;40:807-27, http://dx.doi. org/10.1016/S0020-7489(03)00077-4.

10. Marcelino G, Cerveira JM, Carvalho I, Costa JA, Lopes M, Calado NE, et al. Burnout levels among Portuguese family doctors: A nationwide survey. BMJ Open. 2012;2:e001050, http://dx.doi.org/10.1136/bmjopen-2012-001050.

11. Mikalauskas A, Širvinskas E, Marchertienè I, Macas A, Samalavičius R, Kinduris $\breve{S}$, et al. Burnout among Lithuanian cardiac surgeons and cardiac anesthesiologists. Medicina (Kaunas). 2012;48(9):478-84.

12. Galván ME, Vassallo JC, Rodríguez SP, Otero P, Montonati MM, Cardigni G, et al. Professional burnout in pediatric intensive care units in Argentina. Arch Argent Pediatr. 2012;110(6):466-73.

13. Montero-Marín J, García-Campayo J, Fajó-Pascual M, Carrasco JM, Gascón S, Gili M, et al. Sociodemographic and occupational risk factors associated with the development of different burnout types: The cross-sectional University of Zaragoza study. BMC Psychiatry. 2011;11:49, http://dx.doi. org/10.1186/1471-244X-11-49.

14. Danohoe E, Nawawi A, Wilker L, Schindler T, Jette DU. Factors associated with burnout of physiotherapists in Massachusetts rehabilitation hospitals. Phys Ther. 1993;73: 750-61.

15. Ogiwara S, Hayashi H. Burnout amongst physiotherapists in Ishikawa Prefecture. J Phys Ther Sci. 2002;14:7-13, http:// dx.doi.org/10.1589/jpts.14.7.

16. Li Calzi S, Farinelli M, Alianti L, Manigrasso V, Taroni AM. Physical rehabilitation and burnout: different aspect of the syndrome and comparison between healthcare professionals involved. Eur J Phys Rehabil Med. 2006;42:27-36.

17. Campo M, Weiser S, Koenig K. Job strain in physical therapists. Phys Ther. 2009;89(9):946-56, http://dx.doi. org/10.2522/ptj.20080322.

18. Bakker AB, Demerouti E, Schaufeli WB. Validation of the Maslach Burnout Inventory - General Survey: An Internet 
study. Anxiety Stress Coping. 2002;15:245-60, http://dx.doi. org/10.1080/1061580021000020716.

19. Khanna R, Khanna R. Is medicine turning into unhappy profession? Indian J Occup Environ Med. 2013;17(1):2-6, http://dx.doi.org/10.4103/0019-5278.116363.

20. Hildingsson I, Westlund K, Wiklund I. Burnout in Swedish midwives. Sex Reprod Healthc. 2013;4(3):87-91, http:// dx.doi.org/10.1016/j.srhc.2013.07.001.

21. Tucholska S. [Burnout teachers. Psychological analysis of the phenomenon and its personality determinants]. Lublin: Wydawnictwo KUL; 2009. Polish.

22. Head J, Kivimaki M, Martikainen P, Vahtera J, Ferrie JE, Marmot MG. Influence of change in psychosocial work characteristics on sickness absence: The Whitehall II Study. J Epidemiol Community Health. 2006;60:55-61, http:// dx.doi.org/10.1136/jech.2005.038752.

23. Blackmore ER, Stansfeld SA, Weller I, Munce S, Zagorski BM, Stewart DE. Major depressive episodes and work stress: results from a national population survey. Am J Public Health. 2007;97:2088-93, http://dx.doi.org/10.2105/ AJPH.2006.104406.

24. Clays E, de Bacquer D, Leynen F, Kornitzer M, Kittel F, de Backer G. Job stress and depression symptoms in middleaged workers: prospective results from the Belstress study. Scand J Work Environ Health. 2007;33:252-9, http://dx.doi. org/10.5271/sjweh.1140.

25. Aboa-Eboule C, Brisson C, Maunsell E, Mâsse B, Bourbonnais R, Vézina $\mathrm{M}$, et al. Job strain and risk of acute recurrent coronary heart disease events. J Am Med Assoc. 2007;298:1652-60, http://dx.doi.org/10.1001/jama.298.14.1652.

26. Kornitzer M, de Smet P, Sans S, Dramaixa M, Boulenguezc $\mathrm{C}$, DeBackerd G, et al. Job stress and major coronary events: results from the job stress, absenteeism and coronary heart disease in Europe study. Eur J Cardiovasc Prev Rehabil. 2006;13:695-704, http://dx.doi.org/10.1097/01. hjr.0000221865.19415.e9.

27. Litzke M, Schuh H. [Stress, bullying and burnout]. Gdańsk: Gdańskie Wydawnictwo Psychologiczne; 2007. Polish.
28. Bilska E. [Like a phoenix from the ashes: burnout syndrom]. Nieb Linia. 2004;4:3-7. Polish.

29. Takeuchi R, O'Brien M, Ormond K, Brown S, Maly M. "Moving Forward": Success from a physiotherapist's point of view. Physiother Can. 2008;60(1):19-29, http://dx.doi. org/10.3138/physio/60/1/19.

30. Atwood CA, Woolf DA. Job satisfaction of physical therapists. Health Manage Rev. 1982;7:81-6, http://dx.doi. org/10.1097/00004010-198200710-00012.

31. Randolph DS. Predicting the effect of extrinsic and intrinsic job satisfaction factors on recruitment and retention of rehabilitation professionals. J Health Manage. 2005;50(1):49-60, discussion 60.

32. Chodkiewicz J. [Treatment of alcohol dependence: anxiety and depression and personal resources]. Alkohol Narkom. 2010;23(3):201-16. Polish.

33. Diener E, Lucas E, Oishi S. [Mental well-being. The science of happiness and satisfaction with life]. In: Czapiński J, editor. [Positive psychology]. Warszawa: Wydawnictwo Naukowe PWN; 2004. p. 35-51. Polish.

34. Chodkiewicz J. [Adaptation Poland - Satisfaction with Life Questionnaire (FLZ)]. Studia Psychol. 2009;47:5-21. Polish.

35. Steuden S, Okła W. [Provisional textbook Burnout Scale Force - SWS. Experimental edition]. Lublin: Zakład Psychologii Klinicznej KUL; 1998. Polish.

36. Krause N, Ragland DR, Fisher JM, Syme SL. Psychosocial job factors, physical workload, and incidence of workrelated spinal injury: A 5-year prospective study of urban transit operators. Spine. 1998;23:2507-16, http://dx.doi. org/10.1097/00007632-199812010-00005.

37. Lent RW, Singley D, Sheu HB, Gainor KA, Brenner BR, Treistman D, et al. Social cognitive predictors of domain and life satisfaction: exploring the theoretical precursors of subjective well-being. J Couns Psychol. 2005;52:429-42, http:// dx.doi.org/10.1037/0022-0167.52.3.429.

38. Diener ED, Suh EM, Lucas RE, Smith HL. Subjective wellbeing: three decades of progress. Psychol Bull. 1999;125: 276-302, http://dx.doi.org/10.1037/0033-2909.125.2.276. 
39. Vemuri AW, Costanza R. The role of human, social, built, and natural capital in explaining life satisfaction at the country level: toward a national well-being index (NWI). Ecol Econ. 2006;58:119-33, http://dx.doi.org/10.1016/j.ecolecon. 2005.02.008.

40. Harris PR, Lightsey OR Jr. Constructive thinking as a mediator of the relationship between extraversion, neuroticism, and subjective well-being. Eur J Pers. 2005;19:409-26, http:// dx.doi.org/10.1002/per.544.

41. Benevides-Pereira AM, Das Neves Alves R. A study on burnout syndrome in healthcare providers to people living with HIV. AIDS Care. 2007;19(4):565-71, http://dx.doi. org/10.1080/09540120600722775.

42. Fredrickson BL, Cohn MA, Coffey K, Pek J, Finkel SM. Open hearts build lives: Positive emotions, induced through meditation, build consequential personal resources. J Pers Soc Psychol. 2008;95(5):1045-62, http://dx.doi.org/10.1037/a0013262.

43. Ong AD, Bergeman CS, Bisconti TL, Wallace KA. Psychological resilience, positive emotions, and successful adaptation to stress in later life. J Pers Soc Psychol. 2006;91:730-49, http://dx.doi.org/10.1037/0022-3514.91.4.730.

44. Pavlakis A, Raftopoulos V, Theodorou M. Burnout syndrome in Cypriot physiotherapists: A national survey. BMC Health Serv Res. 2010;10:63, http://dx.doi.org/10.1186/14726963-10-63.

45. Härenstam A. MOA Research Group. Different development trends in working life and increasing occupational stress require new work environment strategies. Work. 2005;24:261-77.

46. Ahola K, Honkonen T, Isometsä E, Kalimo R, Nykyri E, Koskinen S, et al. Burnout in the general population - Results from the Finnish Health 2000 Study. Soc Psychiatry Psychiatr Epidemiol. 2006;41:11-7, http://dx.doi.org/10.1007/ s00127-005-0011-5.

47. Soares JJF, Grossi G, Sundin Ö. Burnout among women: associations with demographic/socio-economic, work, life-style and health factors. Arch Womens Ment Health. 2007;10: 61-71, http://dx.doi.org/10.1007/s00737-007-0170-3.

This work is available in Open Access model and licensed under a Creative Commons Attribution-NonCommercial 3.0 Poland License - http://creativecommons.org/ licenses/by-nc/3.0/pl/deed.en. 